\title{
International Arctic Petroleum Cooperation: Barents Sea Scenarios
}

Anatoli Bourmistrov, Frode Mellemvik, Alexei Bambulyak, Ove Gudmestad, Indra Overland \& Anatoly Zolotukhin (red.)

Abingdon \& New York: Routledge 2015

291 sidor. ISBN 9781138783263

Recenserad av: Ingmar Oldberg [fil.mag., associerad forskare, Utrikespolitiska institutet, Stockholm, ingmar.oldberg@gmail.com]

Detta bidrag till den rika norska forskningen om förhållandet till Ryssland i Arktis präglas dels av förhoppningarna efter sjögränsavtalet 2010, dels bekymren över sanktionerna, som infördes 2014 på grund av Rysslands aggression mot Ukraina. Boken är ett resultat av samarbete mellan forskare inom NAREC (Norwegian and Russian Education and Research Consortium for International Business Development in the Energy Sector) och en mängd möten under flera år. Sex redaktörer, 29 författare och en rad kommentatorer från båda länderna har medverkat, i sanning ett stort projekt, som däri kan jämföras med det finska scenarioprojektet »Russia as a Neighbour» (se min recension i Nordisk Östforum, nr. 4, 2015)

Bokens huvudsyfte har varit att lansera scenarier för det norsk-ryska energisamarbetet i Barentsområdet tio år framåt. I anslutning till en modell utarbetad av oljebolaget Shell eftersträvas inte sannolikhet utan rimlighet och inre koherens. Man utgår från förutsättningar som bedöms som säkra, till exempel låg risk för geopolitisk konflikt i Barents, fortsatt globalt behov av olja och gas, växande asiatisk marknad, klimatförändring som påverkar havsmiljön, svåra väderförhållanden, och intresse för varandras energitillgångar. I dessa faktorer identifieras osäkerheter som hur energipriserna och den asiatiska marknaden utvecklas, spridningen av okonventionell olja och gas, klimatrestriktioner, utvecklingen av Lofotens tillgångar, och tendenser i västliga/norska relationer med Ryssland. Osäkerheterna kombineras sedan till tre scenarier, som blandar positiva och negativa trender, och olika faktorer blir drivande.

Enligt det första scenariot, »After you, Sir», fortsätter energisamarbetet trots Ukraina-krisen men bromsas av att produktionen av okonventionell olja och gas sprids i världen, vilket sänker priser och investeringsvilja. Enligt det andra scenariot kallat »Parallel play, not only for children» intensifieras energiutvinningen i Barentshavet och vid Lofoten av ökad efterfrågan i världen, särskilt i Asien, och av mindre "unconventionals», men på grund av politisk polarisering sker processen $\mathrm{i}$ vart land för sig. Det tredje scenariot, »Let's dance, but where is the music?», siar om gott samarbete mellan Norge och Ryssland i Barentshavet, men fossilindustrin 
hämmas av strängare klimatlagar i bägge (obs!) länderna och stagnerande tillväxt och efterfrågan i Asien.

Projektet lanserar vidare några »wild cards», osannolika, oftast exogena händelser, som får stora effekter och bildar egna miniscenarior. Här nämns möjliga katastrofer som jordbävning i USA som stoppar fracking, global nedkylning, massivt oljespill i Arktis och ekonomiskt sammanbrott i någon ekonomisk stormakt som Kina, USA och EU. Kuriöst nog tas inte Ryssland med här, vilket kan ses som utslag av vad redaktörerna förklarar med kompromisser mellan »stundom högst divergerande världsåskådningar». Ett annat exempel är det »säkra» antagandet ovan att det inte blir någon militär konflikt i Arktis.

Scenariokapitlet bygger på och följs av en rad kapitel om olika väsentliga faktorer, dels politiska och ekonomiska, dels teknologiska och miljörelaterade. Ett upplysande kapitel om den internationella kontexten betonar betydelsen av Asien. Ekonomisk tillväxt där kan å ena sidan öka behovet av petroleum och stimulera investeringar i Barentsregionen, å andra sidan påverka Ryssland att med hjälp av kinesiskt kapital i stället satsa på mindre kostsam energiutvinning i sina östliga delar, medan Norge satsar på Europa, som vill göra sig oberoende av rysk energi. Okonventionell olja och gas kan översvämma marknaden, men klimatrestriktioner kan minska efterfrågan. Ett miljöavtal som följer upp Kyotoprotokollet antas främst kunna hota den smutsiga kolproduktionen i världen - efter bokens tillkomst tycks nu faktiskt miljöavtalet från 2015 i Paris vara i hamn.

Ett faktarikt kapitel om resurshanteringen i Barents hav jämför Norge och Ryssland i frågan om klassificering, licensiering, miljökontroll och beredskap mot oljeutsläpp. Medan Norge ger licenser genom öppen konkurrens, favoriserar Ryssland Gazprom och Rosneft i ett centraliserat, slutet system. Länderna har gemensamma intressen av att bekämpa oljeutsläpp och ett visst samarbete om det, men detta begränsas av bristande samordning av tekniska resurser och metoder samt otydliga definitioner av skadlighet och nollutsläpp. Kapitlet borde dock ha nämnt följderna av att Rysslands ministerier för naturresurser och miljö slogs samman 2008.

Ett kapitel analyserar sedan drivkrafterna för det norsk-ryska energisamarbetet $i$ Barentsområdet. Det visar att båda sidor har behov att utveckla resurserna där och har kompletterande intressen genom att Ryssland har brist på teknologi, know-how och kapital för offshore-utvinning, medan Norge kan bidra med detta på grund av många års erfarenhet. Länderna har samverkat i regionen sedan 1990-talet, vilket utmynnat i Sjtokman-projektet (nu nedlagt) och 2010 års gräns- och samarbetsavtal. Oljeplattformen Prirazlomnaja är fullpackad med norsk teknologi och Statoil är verksamt även i Ochotska havet. Lukoil är med på den norska sidan, men det finns få ryska utrustningsföretag verksamma utomlands. Bristen på gemensamma företag förklaras med den ryska affärskulturen. Författarna förutspår att 2014 års västliga sanktioner mot olje- och gasteknologiexport kommer att leda till rysk satsning på inhemsk produktion och import från Kina, och att båda länderna koncentrerar sig på sina egna resurser, något som nu tycks slå in.

Ett intressant litet kapitel ägnas åt hur olje- och gasutvecklingen i Barents påverkas av ländernas politiska relationer. Det framhålls att länderna haft fred i över tusen år och har bättre relationer än till exempel Sverige-Ryssland, vilket lett till 
lyckade avtal om fiske, energi och gränser. Problemen med Svalbard tonas dock ned. Vid sidan om ekonomiska problem - som minskad efterfrågan på energi, billigare utvinning på Jamal-halvön, kostnader på grund av Ukrainakonflikten och sökande efter nya exportvägar (Nordstream i Östersjön kunde ha nämnts), ökad satsning på den östasiatiska marknaden samt stort utrymme för ökad energieffektivitet - så hotas dock utvecklingen i Barents av Norges deltagande i Natos och EU:s sanktioner mot och kritik av rysk politik på senare år. Detta i sin tur kan förstärka Rysslands militära säkerhetstänkande i Barents på bekostnad av ekonomiskt samarbete, anser författarna mycket förutseende.

Förutom ett kapitel om utbildningssamarbete inom olje- och gassektorn mellan två norska och två ryska universitet, som de flesta redaktörerna varit knutna till, innehåller resten av boken en rad kapitel av mer naturvetenskaplig och teknisk natur - alltifrån Barentshavets geologi och konkreta energiresurser, klimat- och väderproblem till krishantering och miljöeffekter av olje- och gasverksamhet till havs. Sammantaget fungerar boken som en klassisk handbok i Arktiskunskap.

Bokens deklarerade syfte att bidra till multidisciplinär kunskap om förhållandena i Arktis bland forskare, studenter, NGO-folk, politiker och affärsmän uppnås alltså. Scenarierna öppnar blicken för framtida utvecklingsmöjligheter men kan inte förutse framtiden för energimarknaden och de politiska relationerna, som är avgörande faktorer för Barents framtid. Synd bara att förlaget giort boken så dyr. 